\title{
In vitro Evaluation of the Anti Helminthic Activity of Selected Eritrean Traditional Medicinal Plants
}

\author{
Yohana Habte G Amlak ${ }^{1}$, Yohana Ghirme Weldu ${ }^{1}$, Yodit Cheay G Silasie ${ }^{1}$, Ariam Yemane Fisehaye ${ }^{1}$, Jeevan Jyoti \\ kaushik $^{2}$, Dawit Eman ${ }^{2}$ and Hagos Andom Tuumzghi*2
}

${ }^{1} \mathrm{MOH}$, central region, Asmara, Eritrea

${ }^{2}$ Asmara College of Health Sciences, Asmara, Eritrea

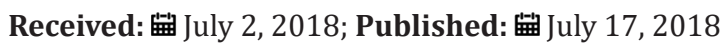

*Corresponding author: Hagos Andom Tuumzghi, MOH, central region, Asmara, Eritrea, PO Box: 8566

\begin{abstract}
The aim of the study was to determine the anti helimentic activity of two medicinal plants (Taget esminuta and Moringa Olifera) in Eritrea. Fractionated extracts of the plants were prepared using different solvents and their anthelminthic activity was tested on earthworms (Pheritimaposthuma).The histopathological studies of the worms was conducted to compare the histological damage on the test animals in comparison with the standard drug. Methodology the anthelminthic activity was carried out on freshly collected adult earthworms (Pheretimapostuma). The study was carried as per method of Ajaiyeoba et al. [1]. The earthworms of similar length and width were subjected to different concentrations of each plant extract. At the same time, positive and negative controls were carried out. Time taken for paralysis and death of individual worms were recorded.
\end{abstract}

Results: The highest yield percentage (22\%) was obtained with aqueous ethanol and chloroform solvents from Moringa Olifera raleaves and with aqueous-ethanol in case of T.minuta leaves. Chloroform extract of Tagetes diminuta showed the most remarkable activity in paralyzing and killing the earthworms whereas aqueous-ethanolic extract of Moringao life era leaves was the most potent extract than the other extracts. From the histopathological studies it was observed that the leaf extract of Moringa Olifera as well as that of T.minuta have worm icidal effect. The fruit extract of Moringa Olifera has better damaging effect than that of the leaf extract of this plant.

Conclusion: Fore going observation on the effect of the extracts of two selected plants lead us to reach the conclusion that both the leaf and fruit extract of M.olifera as well as the leaf extract of TMinuta have worm icidal effect. To conclude, in future studies, there is need for thorough phyto chemical, clinical and possible studies on molecular mechanism of action of these plants.

Keywords: In vitro Evaluation; Medicinal Plants; Anti Helimentic; Eritrea; Moringa Olifera; Phyto Chemical; Helminthes; Anaemia; Eosinophilia; Filter Paper; Autoclave Tape

\section{Introduction}

Human kind has been exposed to infection by microorganism since before the down of recorded history [1]. Diseases caused by intestinal parasites (helimentic) pose a great threat to health and contribute to the prevalence of malnutrition, anaemia and eosinophilia [2]. All cultures have folk medicine traditions that include the use of plants and plant products [3]. Traditional medicinal plants are linked to traditional culture with traditional healers and herbalists acting as important stake holders [3]. The plants are known torpor idea rich source of botanical and the lminthics. It is estimated that two thirds of the world population still rely on traditional medical remedies, mainly plants, because of limited availability and affordability of pharmaceutical medicines [4]. Today more than $70 \%$ of the people in Africa refer to traditional healers concerning health issues [4]. The world health organization (WHO) encourages the inclusion of her bal medicines of proven safety and efficacy in the health care program of developing countries because of the great potential they hold in combating various diseases [4].
Thus, limitations of reliance on chemo therapy are the threat of parasites developing resistance to drug treatment, the cost of drugs for people in developing countries and for some helminthes, lack of efficacy of current available drugs [5]. Therefore, novel and complementary helminthes control options are urgently needed. Taget esminutaltisa strongly scented annual herb with stiff erect stems up to $2 \mathrm{~m}$ tall. Leaves stalked, opposite, light green, $7-15 \mathrm{~cm}$ long, pinnately dissected into 4-6 pairs of pinnate. Secretions from roots are effective against nematodes, worms, insects, fungi and perennial weeds [6]. It has antimicrobial, antiphlogistic, sedative, fungicide and hypertensive properties [6]. Moringa Olifera an often referred to as the "miracletree" because of its uniquely diverse array of nutritional, medicinal, and purifying properties, It is a small or medium sized tree, fast growing deciduous or sharp tree that reaches $12 \mathrm{~min}$ height when mature [6]. It's known to have anti-diabetic, anti-hypertensive, anti- inflammatory, anti-microbial, anti-viral, anti-parasitic, anti-tumor and anti-aging activities [6]. 


\section{Methods and Materials Used}

\section{Collection and Identification of Earth worms}

The assay was performed on adult earthworm (Pheritimaposthuma) owing to it's an atomically and physiological resemblance with the intestinal round worm parasites of human beings. Easy availability of earth worms and free-living lifestyle prompts their extensive use for preliminary in-vitro evaluation of anthelminthic compounds. Earthworms were collected from the water-logged soil besides Expo ground and were identified by an anatomist. All earthworms were of approximately equal size $(15 \mathrm{~cm}$ long).

\section{collection and identification of selected plants}

Two plants (Tagetes diminuta and Moringa Olifera) which are locally used by traditional healers were collected in the month of March 2015 from different locations like Elabered and Asmara and were used for the present experimental study. The leaves of Tagetes diminuta and leaves and fruits of Moringao lie era were used for the present study. The selected plants were authenticated by Botanist. The collected plants were deposited in the department of Clinical Laboratory Sciences, School of Allied Health Profession, ACHS, Asmara.

\section{Standards}

The anthelminthic activity was carried out on freshly collected adult earthworms (Pheretimapostuma). The anti-parasitic activity was carried as per method of Ajaiyeoba et al. [7]. The earthworms were similar in length and width. They were washed with normal salineto remove soil, dust and mud from them and were put in petri-dish. Each Petri dish had three worms of approximately equal size (Figure 1). Three different concentrations of $10 \mathrm{mg} / \mathrm{ml}, 50 \mathrm{mg} /$ $\mathrm{ml}$ and $100 \mathrm{mg} / \mathrm{ml}$ of each plant extract were used. The solutions were introduced into the respective petri-dishes. At the same time, positive (Mebendazole, $20 \mathrm{mg} / \mathrm{ml}$ ) and negative control (normal saline) were carried out.

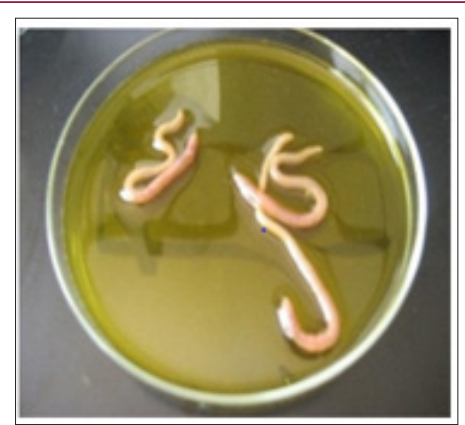

Figure 1: Treatment with $70 \%$ ethanol.

\section{Chemicals}

The two plants were subjected to cold extraction using aqueous ethanol, Petroleum ether, Chloroform; Methanol and percentage yield was obtained.

\section{Extraction method}

The plant materials were washed under running tap water to remove mud and dust. The samples were air-dried for 7 days and were well pulverized into a fine powder with a mixer grinder. The powder was stored in air tight aseptic containers $\left(28^{\circ} \mathrm{C} \pm 2\right)$ for subsequent use. Weighed material (50grameach) was placed in conical flask containing the different solvents and then placed on an electronics haker for 48 hours at the speed of $100 \mathrm{rpm}$. The fluids were then filtered using what man No1 filter paper. The extracts were rotary dried to obtain the concentrate. It was then kept in the fridge $\left(4^{\circ} \mathrm{C}\right)$ prior to use.

\section{Quality Control}

All the equipments used for bioassay were auto calved/heat sterilized. Thepetri-platesand beakers prepared were auto calved at 121 oc for 30 minutes along with Bowiedick autoclave tape. During the analytical process Mebendazole as positive control and normal saline as negative control was used.

\section{Histo-Pathological Studies}

Histo-pathological slides were made from the treated earthworms with plant extracts. Sections from the earthworms in portions before and after the clitellum were selected. Fixations of these portions were made by $10 \%$ form alin for $24 \mathrm{Hrs}$. These fixated pieces were put into the processing machine (alcohol, xyleneand Wax). They were further directed to embedding and moulding in an embedding medium causing them to solidify. The embedded portions were refrigerated, and the cooled portions were cut by amicrotome to 5 micron thickness and were transferred to water (150C). Slides were made and transferred to oven with axylenecoat. The prepared slides were examined by apathologist. Finally, different pictures of the slides were taken and comparison with the control was made.

\section{Statistical Analysis}

The precision of this test methodology was determined by statistical analysis of all results on paralysis (P) and/or death (D) time. Repeatability was considered as the difference between successive results obtained by the same technician under constant conditions on identical worms, in the correct and standard procedure of the test methodology. Reproducibility was considered as the difference between two independent results obtained by different technicians working in different laboratories on identical test worms in the correct and standard procedure of the test methodology.

\section{Results and Discussion}

The highest yield percentage (22\%) was obtained with aqueous ethanol and chloroform solvents from Moringa Olifera leaves. While the lowest yield percentage (7\%) was obtained from the fruits of M.o lifera by using methanol. Similarly highest yield percentage (18\%) was obtained with aqueous ethanol in case of T.minuta leaves and the lowest yield (8\%) was obtained with chloroform and petroleum ether (Table 1). The aqueous ethanol extracts of Targets minuta showed paralysis and death of the earthworms at $17 \pm 2.9 \mathrm{~min}$ and $35 \pm 0.9 \mathrm{~min}$ respectively at highest concentration of $100 \mathrm{mg} / \mathrm{ml}$ and $32 \pm 1 \mathrm{~min}$ and $210 \pm 3.6 \mathrm{~min}$ respectively upon treatment with $10 \mathrm{mg} / \mathrm{ml}$. Results are found to bedose dependent with increasing concentration. 
Table 1: The percentage yield of the selected plants.

\begin{tabular}{|c|c|c|c|c|c|}
\hline Selected plants & Part of plant used & Solvent used & Wt. of the material & Wt. of the Extracts & Yield Value \\
\hline \multirow{4}{*}{ Tagetes diminuta } & Leaves & Aqueous-ethanolic & $50 \mathrm{~g}$ & $9 \mathrm{~g}$ & $18 \%$ \\
\hline & Leaves & Petroleum ether & $50 \mathrm{~g}$ & $4 \mathrm{~g}$ & $8 \%$ \\
\hline & Leaves & Chloroform & $50 \mathrm{~g}$ & $4 \mathrm{~g}$ & $8 \%$ \\
\hline & Leaves & Methanol & $50 \mathrm{~g}$ & $8 \mathrm{~g}$ & $16 \%$ \\
\hline \multirow{4}{*}{ Moringaolifera } & Leaves & Aqueous-ethanolic & $50 \mathrm{~g}$ & $11 \mathrm{~g}$ & $22 \%$ \\
\hline & Leaves & Petroleum ether & $50 \mathrm{~g}$ & $4 \mathrm{~g}$ & $8 \%$ \\
\hline & Leaves & Chloroform & $50 \mathrm{~g}$ & $11 \mathrm{~g}$ & $22 \%$ \\
\hline & Leaves & Methanol & $50 \mathrm{~g}$ & $4 \mathrm{~g}$ & $8 \%$ \\
\hline \multirow{2}{*}{ Moringaolifera } & Fruits & Aqueous-ethanolic & $50 \mathrm{~g}$ & $5 \mathrm{~g}$ & $10 \%$ \\
\hline & Fruits & Methanol & $50 \mathrm{~g}$ & $3.5 \mathrm{~g}$ & $7 \%$ \\
\hline
\end{tabular}

Table 2: Anti Helimentic activity of Moringaolifera and Tagetes diminuta leaves.

\begin{tabular}{|c|c|c|c|c|c|c|}
\hline Group & $\begin{array}{c}\text { Treatment of } \\
\text { extracts }\end{array}$ & $\begin{array}{c}\text { Concentration } \\
(\mathrm{mg} / \mathrm{ml})\end{array}$ & $\begin{array}{c}\text { Time of paralysis } \\
\text { Moringao lif era } \\
\text { leaves(min) }\end{array}$ & $\begin{array}{l}\text { Time of death of } \\
\text { Moringao lif era } \\
\text { leaves(min) }\end{array}$ & $\begin{array}{l}\text { Time of paralysis } \\
\text { of Tagetes diminuta } \\
\text { leaves (min) }\end{array}$ & $\begin{array}{c}\text { Time of death } \\
\text { of Tagetes } \\
\text { diminuta Leaves } \\
\text { (min) }\end{array}$ \\
\hline 1 & Control Saline & - & - & - & - & - \\
\hline 2 & Mebendazole & 20 & $37 \pm 2.1 \mathrm{~min}$ & $60 \pm 2 \min$ & $37 \pm 2.2 \mathrm{~min}$ & $60 \pm 2 \min$ \\
\hline \multirow{3}{*}{3} & \multirow{3}{*}{ Aqueous Ethanol } & 10 & $11 \pm 1.2 \mathrm{~min}$ & $35 \pm 1.25 \mathrm{~min}$ & $32 \pm 1 \mathrm{~min}$ & $210 \pm 3.6 \mathrm{~min}$ \\
\hline & & 50 & $6 \pm 0.6 \mathrm{~min}$ & $20 \pm 2.8 \mathrm{~min}$ & $27 \pm 3.8 \mathrm{~min}$ & $45 \pm 2.6 \mathrm{~min}$ \\
\hline & & 100 & $57 \pm 0.025 \mathrm{sec}$ & $13 \pm 1.25 \mathrm{~min}$ & $17 \pm 2.78 \mathrm{~min}$ & $35 \pm 0.86 \mathrm{~min}$ \\
\hline \multirow{3}{*}{4} & \multirow{3}{*}{ Petroleum Ether } & 10 & $12 \pm 2 \min$ & $50 \pm 4.24 \mathrm{~min}$ & $8 \pm 2 \min$ & $90 \pm 4 \min$ \\
\hline & & 50 & $9 \pm 1.1 \mathrm{~min}$ & $38 \pm 1.6 \mathrm{~min}$ & $7 \pm 1 \min$ & $60 \pm 1.6 \mathrm{~min}$ \\
\hline & & 100 & $6 \pm 1 \mathrm{~min}$ & $20 \pm 3 \min$ & $5 \pm 1 \mathrm{~min}$ & $50 \pm 2.8 \mathrm{~min}$ \\
\hline \multirow{3}{*}{5} & \multirow{3}{*}{ Chloroform } & 10 & $20 \pm 1 \min$ & $58 \pm 0.7 \mathrm{~min}$ & $4 \pm 1.6 \mathrm{~min}$ & $13 \pm 2.1 \mathrm{~min}$ \\
\hline & & 50 & $18 \pm 1.8 \mathrm{~min}$ & $50 \pm 0.5 \mathrm{~min}$ & $2 \pm 1.27 \mathrm{~min}$ & $7 \pm 3.12 \mathrm{~min}$ \\
\hline & & 100 & $16 \pm 2 \min$ & $38 \pm 1 \min$ & $55 \pm 0.6 \mathrm{sec}$ & $4 \pm 0.9 \mathrm{~min}$ \\
\hline \multirow{3}{*}{6} & \multirow{3}{*}{ Methanol } & 10 & $9 \pm 1 \min$ & $53 \pm 2 \min$ & $13 \pm 2.5 \mathrm{~min}$ & $43 \pm 2.26 \mathrm{~min}$ \\
\hline & & 50 & $6 \pm 2 \min$ & $41 \pm 1.7 \mathrm{~min}$ & $9 \pm 2.3 \mathrm{~min}$ & $19 \pm 3.2 \mathrm{~min}$ \\
\hline & & 100 & $4 \pm 0.8 \mathrm{~min}$ & $28 \pm 2 \min$ & $7 \pm 1.5 \mathrm{~min}$ & $12 \pm 2.7 \mathrm{~min}$ \\
\hline
\end{tabular}

Data is an average of two experiments consisting three earthworms in one plate.

All the values represent Mean \pm S.D; $n=3$ in each group.

The death time of earthworm when treated with petroleum ether extract was $50 \pm 2.78 \mathrm{~min}, 60 \pm 1.58 \mathrm{~min}$ and $90 \pm 4 \mathrm{~min}$ respectively using $100 \mathrm{mg} / \mathrm{ml}, 50 \mathrm{mg} / \mathrm{ml}, 10 \mathrm{mg} / \mathrm{ml}$ concentrations, which was observed to have the longest death time as the concentration of plant extract was less than the two higher concentrations. Chloroform extract of Taget esminuta showed the most remarkable activity and paralyzed the earthworms within $55 \pm 0.6 \mathrm{sec}$ using $100 \mathrm{mg} /$ mlof plant concentration, soit can be considered as most potent extract of the plant. The fourth solvent used for the extraction of Tagetes diminuta was methanol. It paralyzed the earthworms at $13 \pm 2.5 \mathrm{~min}, 9 \pm 2.3 \mathrm{~min}$ and $7 \pm 1.5 \mathrm{~min}$ using the $10 \mathrm{mg} / \mathrm{ml}, 50 \mathrm{mg} / \mathrm{ml}$ and $100 \mathrm{mg} / \mathrm{ml}$ concentration while the death time was recorded $43 \pm 2.26 \mathrm{~min}, 19 \pm 3.2 \mathrm{~min}, 12 \pm 2.7 \mathrm{~min}$ for the three concentrations $(10 \mathrm{mg} / \mathrm{ml}, 50 \mathrm{mg} / \mathrm{ml}$ and $(100 \mathrm{mg} / \mathrm{ml})$ (Table 2$)$.

Aqueous ethanolic (70\%ethanol) extract of Moringao lif era showed a variable effect when three different concentrations of $(10 \mathrm{mg} / \mathrm{ml}, 50 \mathrm{mg} / \mathrm{ml}, 100 \mathrm{mg} / \mathrm{ml})$ were used. The highest concentration $(100 \mathrm{mg} / \mathrm{ml})$ resulted in death of earth worms at $13 \pm 1.2 \mathrm{~min}$, whereas at the lowest concentration $(10 \mathrm{mg} /$ $\mathrm{ml}$ ) death was observed at $35 \pm 1.25 \mathrm{mins}$ (Table 2). In the case of Petroleum ether, paralysis of the earth worms was observed in $12 \pm 2$ minfor the lowest concentration and $6 \pm 1$ minfor the highest concentration. Death time with petroleum the extract was recorded at $50 \pm 4.24 \mathrm{~min}, 38 \pm 1.6 \mathrm{~min}$, and $20 \pm 3 \mathrm{~min}$ at $10 \mathrm{mg} / \mathrm{ml}, 50 \mathrm{mg} / \mathrm{ml}$ and $100 \mathrm{mg} / \mathrm{ml}$ concentration respectively. Chloroform extract also showed good and the Iminthic activity. Results clearly indicated that with increased concentration, the effect also increased. Among all the solvents used, Methanol showed the third better activity as the paralysis and death time at the highest concentration wasobservedat $4 \pm 0.8$ minand $28 \pm 2$ minrespectively (Table 2 ).

Aqueous-ethanol and methanol were used for extraction of Moringao lifera fruits. Aqueous- ethanol extract with Concentration of $10 \mathrm{mg} / \mathrm{ml}, 50 \mathrm{mg} / \mathrm{ml}$ and $100 \mathrm{mg} / \mathrm{ml}$ showed a paralysis time in $4 \pm 1.8 \mathrm{~min}, 2 \pm 1.2 \mathrm{~min}$ and $55 \pm 0.4 \mathrm{sec}$ respectively, whereas the death 
time were recorded at $8 \pm 2.1 \mathrm{~min}$ with the highest concentration and $45 \pm 2.7 \mathrm{~min}$ with the lowest concentration. For the methanol extract, paralysis and death time of the earthworms were recorded $50 \pm 0.5 \mathrm{sec}$ and $4 \pm 2.2 \mathrm{~min}$ at the highest concentrations respectively. Both the leaf and fruit extract of M.oliefera have homicidal effect. Also the fruit extract of M.olifera has still better damaging effect than that of leaf extract of this plant. The effect of extracts of Moringa Olifera leaves on the paralysis of the worm, according to the results (Table 3) may be indicated as Aqueous ethanol $>$ Methanol $>$ Petroleum Ether>Chloroform.

Table 3: Anthelminthic activity of Moringao lifera fruits.

\begin{tabular}{|c|c|c|c|c|}
\hline Groups & $\begin{array}{l}\text { Treatment } \\
\text { of extracts } \\
\text { (min) }\end{array}$ & $\begin{array}{c}\text { Concentration } \\
(\mathrm{mg} / \mathrm{ml})\end{array}$ & $\begin{array}{l}\text { Time of } \\
\text { paralysis } \\
\text { (min) }\end{array}$ & $\begin{array}{l}\text { Time of } \\
\text { death } \\
\text { (min) }\end{array}$ \\
\hline 1. & $\begin{array}{l}\text { Control } \\
\text { saline }\end{array}$ & - & - & - \\
\hline 2. & Mebendazole & 20 & $37 \pm 2.1 \mathrm{~min}$ & $60 \pm 2 \mathrm{~min}$ \\
\hline \multirow{3}{*}{3.} & \multirow{3}{*}{$\begin{array}{l}\text { Aqueous } \\
\text { ethanol }\end{array}$} & 10 & $4 \pm 1.8 \mathrm{~min}$ & $45 \pm 2.7 \mathrm{~min}$ \\
\hline & & 50 & $2 \pm 1.2 \mathrm{~min}$ & $40 \pm 1 \mathrm{~min}$ \\
\hline & & 100 & $55 \pm 0.8 \mathrm{sec}$ & $8 \pm 2.1 \mathrm{~min}$ \\
\hline \multirow{3}{*}{4.} & \multirow{3}{*}{ Methanol } & 10 & $3 \pm 2.3 \mathrm{~min}$ & $20 \pm 4.4 \mathrm{~min}$ \\
\hline & & 50 & $2 \pm 0.8 \mathrm{~min}$ & $12 \pm 4.35 \mathrm{~min}$ \\
\hline & & 100 & $50 \pm 0.5 \mathrm{sec}$ & $4 \pm 2.2 \mathrm{~min}$ \\
\hline
\end{tabular}

Data is an average of two experiments consisting three earthworms in one plate.

All the values represent Mean \pm S.D; $n=3$ in each group.

The combination of the M.olifera (fruit and leaves) and T. Minuta (leaves) showed paralysis at $15 \pm 3$ min with the lowest concentration of Aqueous ethanolic extract and at $3 \pm 2 \mathrm{~min}$ with the highest concentration, where as death time was recorded at $40 \pm 3.6 \mathrm{~min}$ and $12 \pm 3 \mathrm{~min}$ respectively. The $50 \mathrm{mg} / \mathrm{ml}$ concentrations paralyzed the earthworms within $8 \pm 1 \mathrm{~min}$ and killed them in $20 \pm 4$. $2 \mathrm{~min}$. Theplants' extractives showed the lminthic activity and were dose-dependent that increase in concentration of plant showed increased destruction on earthworms. In the combination, the antihelminthic activity of aqueous ethanolic extracts of M.oliefera (fruit and leaves) was reduced when tested in combination with $\mathrm{T}$. Minutaal though acleardose-dependent effect indicating increased activity with increased concentration has been found (Figure 2).

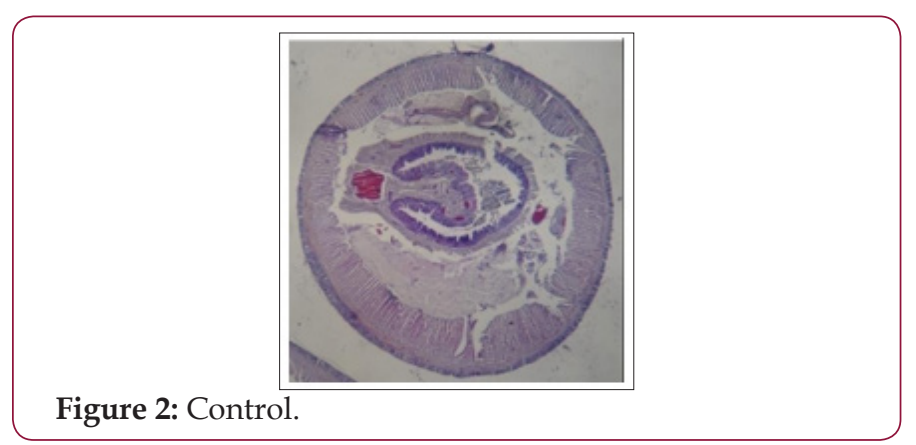

Similar kind of study was done by Vidyadhar et al. in2010 on various extracts of the whole plant of Enicostemmalittorale. Various concentrations $(25,50,100,200 \mathrm{mg} / \mathrm{ml})$ of all extracts were tested and results were expressed interms of time for paralysis and time for death of worms. Albendazole was used as a reference standard and saline as a control group. The ethanol extract showed more significant effect on paralyzing the worms, in terms of paralysis time, at every concentration compared to that of ethyl acetate, water, chloroform, hexane extracts. In particular the ethanol extract exhibited an increased paralytic as well as helimentic effect overall bendazol eat the given experimental concentrations [8].

In another study the root part of Capparisdecidua Edge was evaluated for the an the lminthic activity of the plant at 10, 50 and $100 \mathrm{mg} \backslash \mathrm{ml}$ using ethanol as the main extraction solvent against Indian earthworm Pheritimaposthuma. The activity was found dose dependent compared with the standard drugusedat $10 \mathrm{mg} /$ mlas activity increased with increase concentration of plant [9]. A study conducted on the anti-helminthic activity of the drupe extracts of MeliaazedarachL. (Meliaceae) growing in Argentina against a tape worm and an earthworm, showed to be better than the standard piperazine phosphate, which is used in the treatment of Cestoda infections as it showed mean paralysis and death time value at $32 \mathrm{~min}$ and $68 \mathrm{~min}$ using $70 \%$ Ethanol at high $(80 \mathrm{mg} \backslash \mathrm{ml})$ and low (20mg \ml) concentration [10].

In the present study when the fruits of Moringa Olifera were extracted in aqueous ethanol (70\%) and methanol, both showed excellent an Iminthic activity. The earthworms were paralyzed in $55 \pm 0.8 \mathrm{sec}$ and $50 \pm 0.5 \mathrm{sec}$ in aqueous ethanol (70\%) and methanol extracts respectively at $100 \mathrm{mg} / \mathrm{ml}$ while death was caused at $8 \pm 2.1 \mathrm{~min}$ with aqueous ethanol extract and $4 \pm 2.2 \mathrm{~min}$ with methanol extract at same concentration. Several studies showed that extracts from plants grown to serve as human food for example: coconut, onion and garlic, annan as, chicory have high Anti Helmentic potential against intestinal nematodes, cestodes, and trematodes [11].

\section{Histo pathological studies}

Effect of treatment with Tagetes diminuta extract: Histo pathological observations revealed that treatment of earthworms with leaf extract of T.minuta at $100 \mathrm{mg} / \mathrm{ml}$ (Chloroform extract) were effective. The epidermis and the overlying cuticle were damaged; epidermal cells appeared to be bulged. There was reduction in the height of circular muscle layer (CML) and longitudinal muscle layer (LML) in comparison to the control (saline).The coelomicsepta and gut epithelium appeared to be distorted. The vasculature of the body and the VNC were found to be intact. The histopathological damages due to these extracted plants were compared to that of control animal picture (Figure 3).

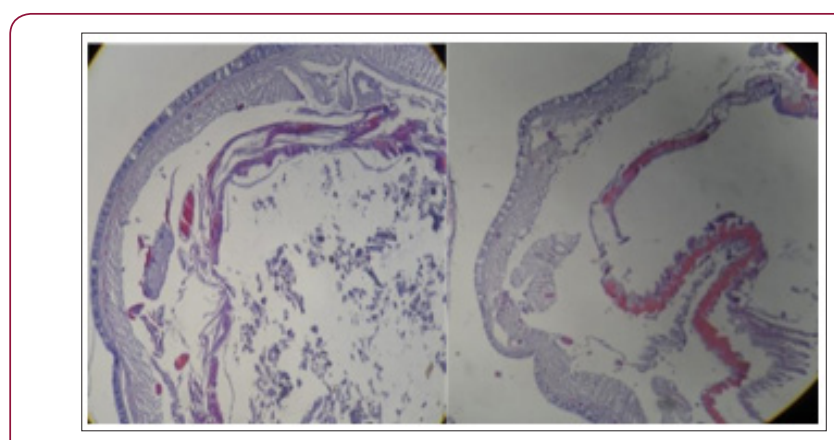

Figure 3: HS of T. Minuta leaves.

Cite this article: Yohana H, Hagos Andom T, Yohana G, Yodit C, Ariam Y, Jeevan Jyoti k, et.al. Invitro Evaluation of the Anti-Helminthic Activity of Selected Eritrean Traditional Medicinal Plants. Biomed J Sci\&Tech Res 6(5)- 2018. BJSTR. MS.ID.001425. DOI: 10.26717/ BJSTR.2018.06.001425. 


\section{Effect of treatment with Moringa Olifera extracts}

Histo pathological studies revealed that animals treated with leaf extracts of M.olifera (100 mg/mlof 70\%-ethanol) showed damaging effect on their body wall as well as visceral organs. The epiderm is of the body wall was more or less completely destroyed. Epidermal cells were variously damaged, although cuticle, the upper most lining of the body wall was less affected. The musculature of the body wall has also showed reduction. The CML and LML appeared to be reduced in their height in comparison to the selayer of normal control animals. The visceral organs such as coelomicsepta (CS) and gutepi the lium were completely dismantled. However, the dorsal and ventral blood vessels were found to be less affected. The ventralnervecord (VNC) on the other hand was intact (Figure 4). It is worth to mention here that fruit extract of same plant was more effective than its leaf extract (Figure 5)

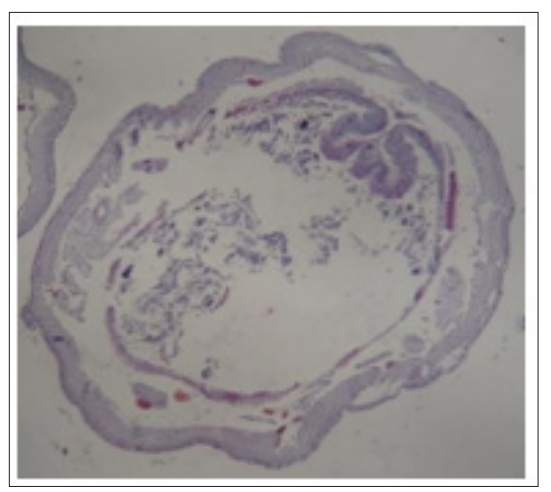

Figure 4: HS of M.olifera leaves.

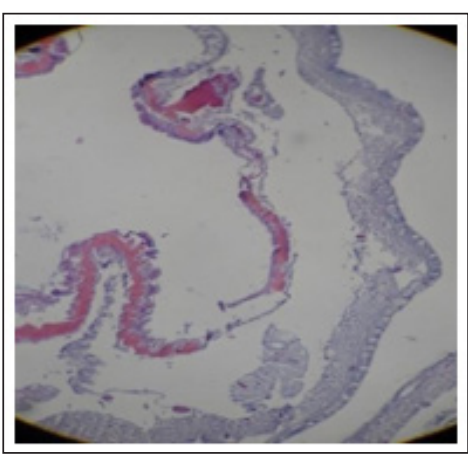

Figure 5: HS of M.olifera fruits.

\section{Effect of treatment with combined extracts}

The histopathological studies pertaining to effect of combined extracts of M.olifera and T. Minuta on the experimental worm revealed that there was no remarkable damage on the body wall. However, the epidermal cells seemed to be partly damaged. The cell size was relatively enlarged and some of the cells were completely damaged. The height of CML and LML was also reduced as it was observed in animals treated with leaf extracts of both plants. The visceral organs such as coelomic septa and gut were also damaged to a large extent. Vasculature and nervous tissues, especially VNC do not seem to be much affected (Figure 6). Animals treated with reference drug did not show any remarkable damaging effect on the tissues.

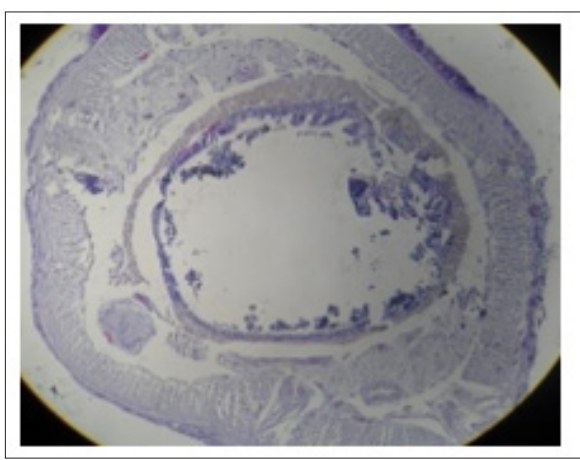

Figure 6: HS of combined extracts

\section{Conclusion}

The present study was an attempt to conduct in vitro antihelminthic activity of selected Eritrie an medicinal plant to substantiate the folk claim. This study reveals new scientific information about the leaf extracts of Taget esminuta and leaf and fruits extractives of Moringa Olifera rain regard to a the lminthic activity. The plants' extractives showed a the Iminthic activity and were dose-dependent that increase in concentration of plant showed increased activity on earthworms.

Fore going observation on the effect of the extracts of the two selected plants lead us to reach the conclusion that both the leaf and fruit extract of M.olifera as well as the leaf extract of T.Minuta have wormicidal effect. Also the fruit extract of M.olifera has still better damaging effect than that of leaf extract of this plant. Present observation suggests that these herbal materials should be regularly used to get protected from the ill effects of the worms because these herbs have worm icidal effects. The exact mechanism of action of these plants is not known. However, it is apparent that these extracts cause damage to tissues of worms. Since these plant extracts have quick paralytic effect, it is advisable to make regular use of such herbs. Because once the worm is paralyzed, there is likely hood of worms to be easily flushed out from the body.

To conclude, in future studies, there is need for thorough phyto chemical, clinical and possible studies on molecular mechanism of action. At the same time efforts should be made to standardize the plant extracts with good antihelminthic activity and formulate best alternative herbal preparations to replace or complement the synthetic drugs which are currently in use (Table1)

\section{Acknowledgement}

We thank Almighty God for enabling us to finish our research. We also thank to: HRD committee for research approval: Mr. NahomFessehaye, (Head of CLS) Dr: AtulKaushik, (School of pharmacy) Dr. Ghebrehiwet Medhanie, (Botany: Plants taxonomy); Prof.S.D. Pandey; Mr DawitTesfay Mr. Tesfamariam Mehari: Head of histopathology Department, NHL. Finally, our special gratitude goes to our family and friends for their continuous moral and financial support.

\section{References}

1. AshutoshKar (2012) Medicinal chemistry: Newer drugs for newer diseases: 4th Ed: New age international publishers 30: 864-865. 
2. Francesco Capasso, Gaginella TS, Grondolini G, Izzo AA (2012) Phototherapy: A quick reference to herbal medicine Pp: 3-6.

3. Ministry of health, State of Eritrea: E.S.T.G: 1stEd: Ministry of Health Asmara: 1996

4. WHO: Traditional medicine and modern health care: progress report by the Director General. Geneva: World Health Organization 1991

5. Sutherland IA, Leathwick DM (2011) Anthelmintic resistance in nematode parasites of cattle: a global issue? Treands parasitol 27(4): 176-181.

6. WHO: Overview on Medicinal Plants and Traditional Medicine in AfricaCAI26/04/04.

7. Ajaiyeoba EO, Onocha PA, Olarenwaju OT (2001) In vitro anthelmintic properties of Buchholzia coriaceae and Gynandropsis gynandra extract. Pharm Biol 39: 217-220.

\section{ISSN: 2574-1241}

DOI: 10.26717/BJSTR.2018.06.001425

Hagos Andom Tuumzghi. Biomed J Sci \& Tech Res

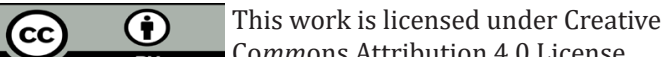

Submission Link: https://biomedres.us/submit-manuscript.php
8. Vidyadhar S, Saidulu M, Gopal TK, Chamundeeswari D, Rao U et al. (2010) Invitro anthelmintic activity of the whole plant of Enicostemma littorale by using various extracts. IntJ Appl Biol Pharma Tech 1(3): 1119-1126.

9. Mali RG, Mehta AA (2008) A review on anti-helmintic plants, Natural product Radiance 7(5): 466-475.

10. Szewezuk VD, Mongelli ER, Pomillio AB (2003) Anti parasitic activity of Meliaazedarach growing in Argentina. Mol Med chem 1: 54-57.

11. Abdel Ghaffar F, Semmler M, Al Rasheid KAS, Strassen B, Fischer K et al. (2011) The effects of different plant extracts on intestinal cestodes and on trematodes. Parasitol Res 108(4): 979-984.

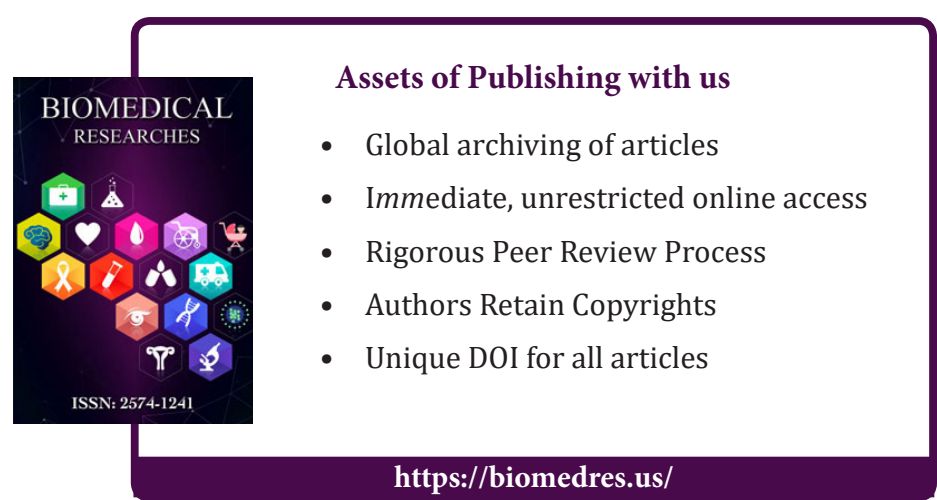

